\title{
Do species traits determine patterns of wood production in Amazonian forests?
}

\author{
T. R. Baker ${ }^{1}$, O. L. Phillips ${ }^{1}$, W. F. Laurance ${ }^{2}$, N. C. A. Pitman ${ }^{3}$, S. Almeida ${ }^{4}$, L. Arroyo ${ }^{5}$, A. DiFiore ${ }^{6}$, T. Erwin ${ }^{7}$, \\ N. Higuchi ${ }^{8}$, T. J. Killeen ${ }^{9}$, S. G. Laurance ${ }^{2}$, H. Nascimento $^{10}$, A. Monteagudo ${ }^{11}$, D. A. Neill ${ }^{12}$, J. N. M. Silva ${ }^{13,14}$, \\ Y. Malhi ${ }^{15}$, G. López Gonzalez ${ }^{1}$, J. Peacock ${ }^{1}$, C. A. Quesada ${ }^{1}$, S. L. Lewis ${ }^{1}$, and J. Lloyd ${ }^{1}$ \\ ${ }^{1}$ Earth and Biosphere Institute, School of Geography, University of Leeds, Leeds, UK \\ ${ }^{2}$ Smithsonian Tropical Research Institute, Balboa, Panama \\ ${ }^{3}$ Center for Tropical Conservation, Duke University, Durham, USA \\ ${ }^{4}$ Museu Paraense Emilio Goeldi, Belém, Brazil \\ ${ }^{5}$ Museo Noel Kempff Mercado, Santa Cruz, Bolivia \\ ${ }^{6}$ Department of Anthropology, New York University, NY, USA \\ ${ }^{7}$ Smithsonian Institution, Washington DC, USA \\ ${ }^{8}$ Instituto Nacional de Pesquisas da Amazônia, Manaus, Brazil \\ ${ }^{9}$ Center for Applied Biodiversity Science, Conservation International, Washington DC, USA \\ ${ }^{10}$ Biological Dynamics of Forest Fragments Project, Manaus, Brazil \\ ${ }^{11}$ Proyecto Flora del Perú, Jardin Botanico de Missouri, Oxapampa, Perú \\ ${ }^{12}$ Missouri Botanical Garden, c/o Naturaleza y Cultura Internacional, Loja, Ecuador \\ ${ }^{13}$ Center for International Forestry Research, Tapajos, Brazil \\ ${ }^{14}$ EMBRAPA Amazonia Oriental, Belém, Brazil \\ ${ }^{15}$ Oxford University Centre for the Environment, Oxford, UK
}

Received: 22 July 2008 - Published in Biogeosciences Discuss.: 9 September 2008

Revised: 19 December 2008 - Accepted: 17 February 2009 - Published: 25 February 2009

\begin{abstract}
Understanding the relationships between plant traits and ecosystem properties at large spatial scales is important for predicting how compositional change will affect carbon cycling in tropical forests. In this study, we examine the relationships between species wood density, maximum height and above-ground, coarse wood production of trees $\geq 10 \mathrm{~cm}$ diameter (CWP) for 60 Amazonian forest plots. Average species maximum height and wood density are lower in Western than Eastern Amazonia and are negatively correlated with CWP. To test the hypothesis that variation in these traits causes the variation in CWP, we generate plot-level estimates of CWP by resampling the full distribution of tree biomass growth rates whilst maintaining the appropriate tree-diameter and functional-trait distributions for each plot. These estimates are then compared with the observed values. Over-
\end{abstract}

all, the estimates do not predict the observed, regional-scale pattern of CWP, suggesting that the variation in communitylevel trait values does not determine variation in coarse wood productivity in Amazonian forests. Instead, the regional gradient in CWP is caused by higher biomass growth rates across all tree types in Western Amazonia. Therefore, the regional gradient in CWP is driven primarily by environmental factors, rather than the particular functional composition of each stand. These results contrast with previous findings for forest biomass, where variation in wood density, associated with variation in species composition, is an important driver of regional-scale patterns in above-ground biomass. Therefore, in tropical forests, above-ground wood productivity may be less sensitive than biomass to compositional change that alters community-level averages of these plant traits. 


\section{Introduction}

Understanding the roles of species composition and abiotic factors on ecosystem properties at large spatial and temporal scales is important for predicting how feedbacks from compositional change might influence patterns of carbon cycling (Hooper et al., 2005). This issue is particularly important in tropical forests because these communities contain $60 \%$ of the carbon stored in living and dead vegetation in forest ecosystems worldwide (Dixon et al., 1994) and long-term changes in the composition of old-growth forests have been documented (Phillips et al., 2002; Laurance et al., 2004). However, the mechanistic links between tropical forest composition and ecosystem function are poorly studied and this is reflected in the very simple representations of plant functional composition in tropical forests that are currently used in dynamic vegetation models (Prentice et al., 2007). Experimental studies of the relationships between biodiversity and ecosystem function have shown that plant traits have an important role in determining the relationships between species composition and ecosystem properties (Diaz and Cabido 2001). Therefore, to predict how feedbacks between environmental and compositional change might operate at large scales in tropical forests, there is a need to test whether current patterns of ecosystem properties are determined by variation in plant traits.

In this study, we focus on the role of two traits, wood density and species maximum height, for determining the patterns of above-ground, coarse wood production of trees $\geq 10 \mathrm{~cm}$ diameter (CWP-Mg Cha ${ }^{-1} \mathrm{a}^{-1}$ ) in Amazonian forests. These traits quantify species' positions along the two major axes of functional variation found in tropical trees - light demand and maximum size (Turner, 2001; Baker et al., 2003) - and both traits are related to variation in plant growth. For example, plot-based studies have shown that low wood density and higher stature species have higher diameter growth rates than high wood density and lower stature species (Lieberman and Lieberman, 1987; Poorter et al., 2008b). In addition, low wood density and greater maximum size is related to higher photosynthetic capacity and leaf nutrient concentrations on an area basis (Santiago et al., 2004; Thomas and Bazzaz, 1999; Falster and Westoby, 2005). Community-level averages of these traits calculated as means across species, or weighted by species abundance or basal area (c.f. Baker et al., 2004b; Garnier et al., 2004) also vary between forests. For example, in Amazonian forests, it is well-established that there is an east-west gradient in average wood density (Baker et al., 2004b; Chave et al., 2006; ter Steege et al., 2006) that matches the threefold variation in CWP (Malhi et al., 2004). Spatial variation in average maximum height is less well-studied, but a pantropical comparison of the composition of the understorey community in several large plots, found that a Western Amazon forest had a particularly high abundance of small stature species (LaFrankie et al., 2006). Such spatial variation in community-level traits implies that they could have an important role in determining variation in stand-level processes.

A range of approaches has been used to examine trait/ecosystem function relationships at large scales in plant communities. These techniques include correlational studies (Vilà et al., 2007), studies of how ecosystem function is distributed across the individuals in a community (Balvanera et al., 2005), approaches where the variation in productivity is decomposed into the differences caused by the abundance, biomass or growth rates of different species or functional groups (Lavorel and Garnier, 2002; Garnier et al., 2004), or resampling approaches to examine the effect of different extinction scenarios (Bunker et al., 2005). In broad terms, the choice of technique distinguishes studies that aim to measure the associations between traits and ecosystem properties (e.g. Vilà et al., 2007), from those that attempt to tease apart the mechanisms that underlie these relationships (e.g. Lavorel and Garnier, 2002). Here, we contrast the insights that both a correlational and a more mechanistic analysis based on resampling give for understanding the relationships between plant traits and CWP in 60 forest plots in Amazonian forests.

In this study, we test the hypothesis that variation in functional composition, rather than environmental factors, determines the three-fold variation in CWP across Amazonia. We use a resampling approach built on creating a null distribution of individual tree biomass growth rates from all plots, and then resampling this distribution according to the specific functional-trait and tree-diameter distributions measured at individual sites. The estimates of CWP that are generated for each plot are then compared with the observed values. If the functional composition of the stand determines variation in observed CWP, then the estimates based on resampled stands of equivalent functional composition should closely correlate with the observed values.

\section{Materials and methods}

\subsection{Forest plot data}

This study used inventory data of all trees $\geq 10 \mathrm{~cm}$ diameter in 60 forest plots across Amazonia, from the RAINFOR database (Peacock et al., 2007, Fig. 1). These plots were categorised into three regions (Northwest, Southwest and Central and Eastern Amazonia, Fig. 1) with similar numbers of plots, and in total cover 79.9 ha. The three regions differ broadly in both climate and soils. Forests in Northwestern Amazonia have an aseasonal climate, typically with $0-1$ month per year with less than $100 \mathrm{~mm}$ rainfall. In contrast, forests in both Southwestern and Central and Eastern Amazonia generally experience a 3-4 month dry season (Sombroek, 2000). In terms of edaphic conditions, the forest plots in Central and Eastern Amazonia are found on predominantly infertile oxisols, whereas more fertile soils are found in lowland forests in Western Amazonia (Sombroek, 2000). Most 


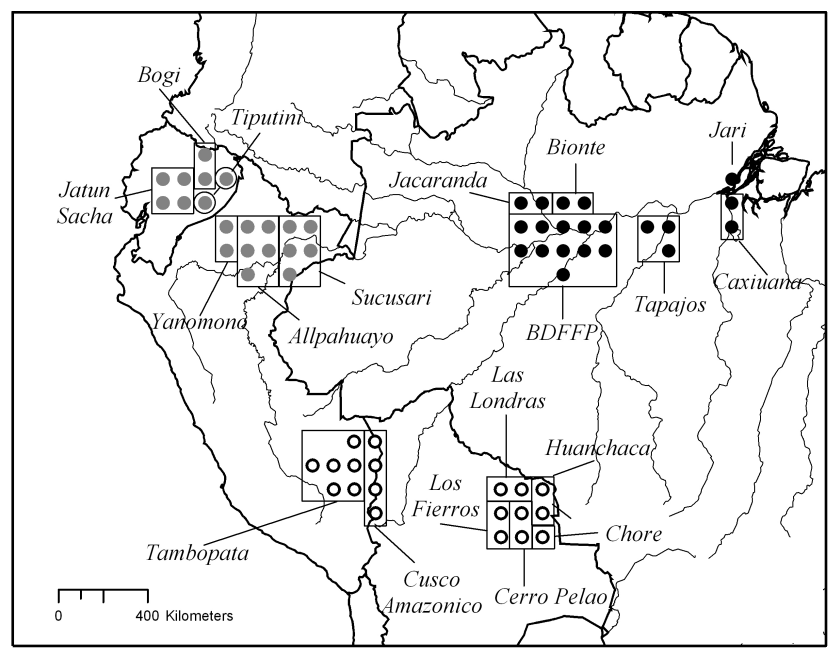

Fig. 1. Location of 60 permanent forest plots in Amazonia. Grey circles, Northwestern Amazonia; open circles, Southwestern Amazonia; black circles, Central and Eastern Amazonia. For clarity, plot location is approximate.

plots are located on tierra firme sites, on clay rich soils. However, a number of the forest plots in Northwestern Amazonia (ALP-12, 21 and 30) are located on white sands and one plot (SUC-03) is seasonally flooded.

Plots have been selected to sample the range of environmental conditions at local and regional scales within Amazonian forests (Malhi et al., 2002). Each plot is typically 1 ha and has data for two or more consecutive censuses, collected using standardised protocols (Baker et al., 2004b), and diameter growth rates have been checked on a tree-by-tree basis, and outliers treated following procedures described in Baker et al. (2004a).

One census interval was chosen from each plot to calculate tree growth rates. Census-interval choice was dictated by the need to sample tree growth rates across equivalent time periods and to minimise variation in census-interval length among plots. The data selected therefore incorporate the most recent measurement where data were available and the previous census that fulfilled these conditions. Although there is inevitably some interplot variability, census interval length $\left(F_{2,57}=1.88\right.$; overall mean $4.8 \pm 0.1$ years $)$, start $\left(F_{2,57}=2.44\right.$; overall mean 1997. $\left.3 \pm 0.3\right)$ and end year $\left(F_{2,57}=1.92\right.$; overall mean $\left.2002.2 \pm 0.3\right)$ do not differ significantly among regions. In total, the initial census data comprised 48879 stems, $79.5 \%$ identified to species, $93.3 \%$ to genus and $94.8 \%$ to family, amounting to 2119 identified species in 535 genera and 89 families. For five, recently established plots not included in Malhi et al. (2004), values of observed CWP comparable to those published in Malhi et al. (2004) were calculated with a correction for census interval length.
Table 1. Five most diverse families of understorey trees $\geq 10 \mathrm{~cm}$ diameter, in three regions of Amazonia, in descending order of species richness.

\begin{tabular}{lll}
\hline $\begin{array}{l}\text { Northwestern } \\
\text { Amazonia }\end{array}$ & $\begin{array}{l}\text { Central and } \\
\text { Eastern Amazonia }\end{array}$ & $\begin{array}{l}\text { Southwestern } \\
\text { Amazonia }\end{array}$ \\
\hline Fabaceae & Annonaceae & Fabaceae \\
Rubiaceae & Myrtaceae & Salicaceae \\
Salicaceae & Fabaceae & Euphorbiaceae \\
Euphorbiaceae & Burseraceae & Melastomataceae \\
Annonaceae & Sapindaceae & Rubiaceae \\
\hline
\end{tabular}

\subsection{Trait data}

Maximum height data $(\mathrm{m})$ was sourced from regional floras (Vásquez Martínez, 1997, 732 species; Ribeiro et al., 1999, 21 species; Killeen et al., 1993, 325 species, excluding height estimates for values based on single sterile specimens) and previous compilations from floras and monographs (Chave, 1999, 498 species; Pitman et al., 2001, 452 species). Specimen records including height estimates were also obtained from the Missouri Botanical Garden TROPICOS database via SALVIAS (The SALVIAS Project, 2002 and onward), and the 95th percentile of the distribution of height values used as a measure of maximum height (202 species). Overall, maximum height data were obtained for 1358 species and average values were calculated for species where more than one estimate of maximum height was available. Maximum height estimates are phylogenetically constrained (variance components analysis for maximum height dataset: $28.5 \pm 4.5 \%$ of variation explained by differences among genera, and a further $24.1 \pm 7.1 \%$ by variation across families), similar to literature wood density values (Baker et al., 2004b; Chave et al., 2006), so for species where no data was available, or those stems not identified to species-level, generic- or familylevel means were used to allocate values, following Baker et al. (2004a).

Different families contribute to the diversity of the understorey (maximum height $<20 \mathrm{~m}$ ) in Western and Eastern Amazonia (Table 1) and maximum height averaged across species is $14 \%$ lower in the plots in western compared to Central and Eastern Amazonia $\left(F_{2,57}=35.6, \mathrm{p}<0.001\right.$, Fig. 2). This regional difference is also significant if the means are computed on a per-stems $\left(F_{2,57}=10.6, \mathrm{p}<0.001\right)$ or basal-area basis $\left(F_{2,57}=5.6, \mathrm{p}<0.01\right)$. These differences occur because of variation in the relative abundance and species richness of understorey trees in different parts of Amazonia (Fig. 2).

Wood density data (dry mass/green volume) was derived from a compilation from across the neotropics (Chave et al., 2006) that currently contains data for 2573 species, from over 5400 individual measurements, and was matched to 

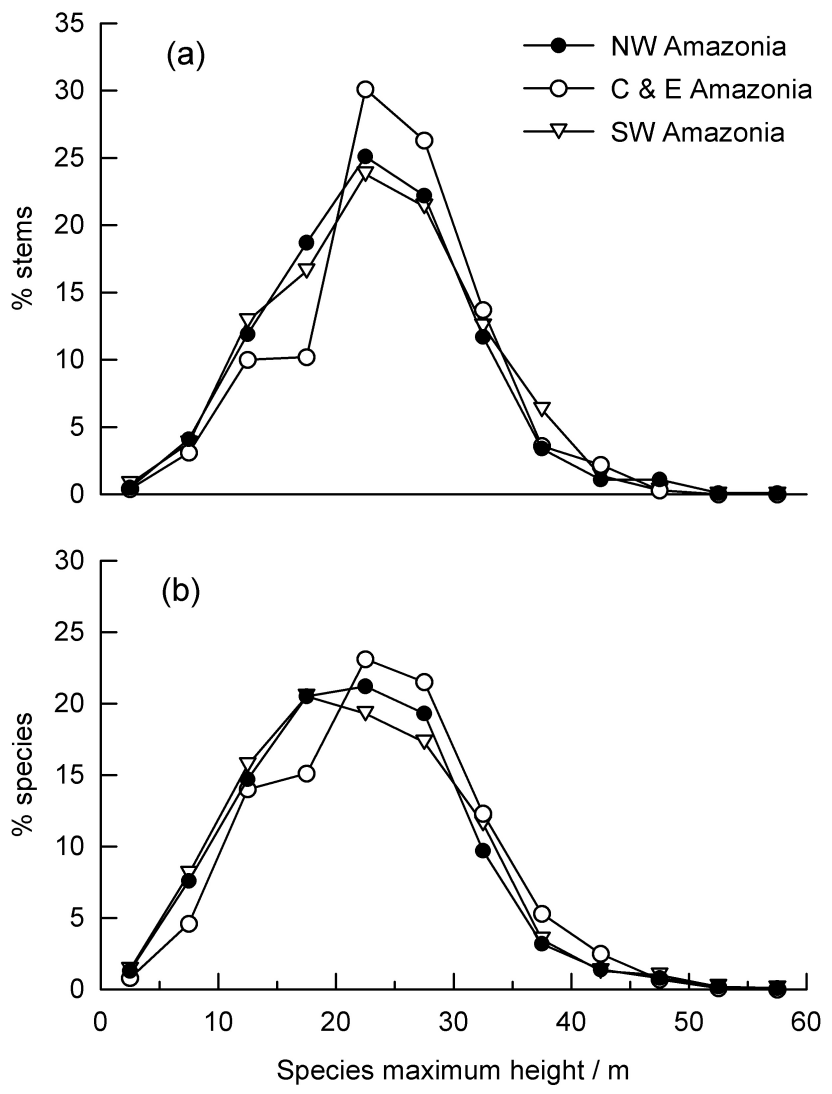

Fig. 2. Relative abundance of (a) stems, and (b) species of different maximum heights, in three regions of Amazonia.

the plot data following the procedures described in Baker et al. (2004b). In this study, $73.3 \%$ of stems identified to species-level were allocated a species-level match for maximum height, and $64.7 \%$ for wood density.

\subsection{Data analysis}

Firstly, regression analysis and a simple mixed model (Galwey 2006) with region as a random factor was used to examine the associations between observed CWP, communitylevel average wood density and maximum height.

Secondly, a resampling approach was used to test the hypothesis that variation in trait values causes the regional-scale variation in CWP. A null distribution from the full dataset of tree growth rates was created by resampling, with replacement, 200 trees from each diameter, wood density and maximum height class from each of the three regions. The limits of these classes were defined using eight different models (Table 2) to examine whether the results were sensitive to the inclusion or exclusion of information on variation in the diameter-class distributions or arbitrary decisions about the cutoff points used for resampling the wood-density, maximum-height and diameter-class distributions. Essentially, each model represents a slightly different way of defin- ing the functional composition of the stand. Estimates of CWP for each plot were then generated by resampling the null distribution according to the frequency of stems in the diameter- and functional-trait classes of each plot. Mean plot-level estimates of CWP for each model were calculated from 1000 replicates of this procedure.

The mean estimated values were then compared with observed values of CWP and ANCOVA was used to test (1) whether estimated values correlated with observed values, and (2) whether there was a significant difference in estimated values between regions (Table 3). The presence of a significant regional term in the ANCOVA indicates that the estimated values, based only on different aspects of the diameter-class and trait distributions, were not able to predict the regional difference in observed CWP.

Growth was calculated as the difference in biomass estimated using two different allometric relationships between diameter and tree biomass developed (1) for forests near Manaus, with a correction factor to account for variation in wood density (Baker et al., 2004b; Chambers et al., 2000, Eq. 2.1) and (2) for all moist tropical forests, incorporating terms for tree diameter and wood density, based on a pantropical compilation of tree biomass data (moist forest equation, excluding tree height, Chave et al., 2005). Palms and Strelitziaceae, which have no secondary growth, were excluded from this analysis.

Finally, we examined whether there were regional differences in growth rates across different types of tree by comparing average biomass growth rates of individuals of the different functional classes defined on the basis of model 7 (Table 2). As distributions of growth rates are strongly skewed, the mean and asymmetric 95\% confidence limits of biomass growth rates across individuals for each combination of trait values were determined from the distribution of growth rates obtained by resampling 100 stems for each combination, 1000 times. Significant differences between groups were inferred by non-overlapping confidence limits.

All analyses were performed in R 2.7.2.

\section{Results}

\subsection{Associations between traits and CWP}

Across all plots, both wood density and average maximum height are negatively correlated with CWP (Fig. 3; stems basis, wood density, $t=-7.20, r^{2}=0.46, p<0.001$; maximum height, $\left.t=-3.65, r^{2}=0.17, p<0.001\right)$. However, a mixed model with region as a random factor and wood density and maximum height as covariates, shows that only wood density has a significant effect $\left(F_{1,57}=12.33, p<0.001\right)$. Overall, plots in Western Amazonia with higher rates of CWP, typically have a greater relative abundance of stems of taxa with low wood density and low maximum heights (Figs. 2 
Table 2. Eight models for detecting whether functional composition, defined on the basis of wood density and maximum height, determines variation in CWP in Amazonian forests. The different models were used to test whether variation in diameter class distribution (models 1 and 2), functional composition (models 3-5) or both diameter class distribution and functional composition (models 6-8) determines variation in CWP. Within each group of models, different bin sizes were used for resampling to test the sensitivity of the results to particular cut-off points.

\begin{tabular}{|c|c|c|c|c|c|c|c|}
\hline \multicolumn{2}{|r|}{ Model } & \multicolumn{6}{|c|}{ Number and lower limits of bins for resampling } \\
\hline & \multirow[b]{2}{*}{ Tests whether: } & \multicolumn{2}{|c|}{ Wood density $\left(\mathrm{g} \mathrm{cm}^{-3}\right)$} & \multicolumn{2}{|c|}{ Max. height (m) } & \multicolumn{2}{|c|}{ Diameter $(\mathrm{cm})$} \\
\hline & & No. bins & Limits & No. bins & Limits & No. bins & Limits \\
\hline 1 & Variation in diameter class dis- & & & & & 3 & $10,20,30$ \\
\hline 2 & $\begin{array}{l}\text { tribution determines variation in } \\
\text { CWP }\end{array}$ & & & & & 3 & $10,20,40$ \\
\hline 3 & Variation in functional composi- & 6 & $0,0.55,0.6,0.65,0.7,0.8$ & 6 & $0,15,20,25,30,35$ & & \\
\hline 4 & tion determines variation in CWP & 3 & $0,0.5,0.7$ & 3 & $0,20,30$ & & \\
\hline 5 & & 15 & $\begin{array}{l}0,0.4,0.45,0.5,0.55,0.6,0.625,0.65,0.675 \\
0.7,0.725,0.75,0.775,0.8,0.85\end{array}$ & & & & \\
\hline 6 & Variation in functional compo- & 6 & $0,0.55,0.6,0.65,0.7,0.8$ & 6 & $0,15,20,25,30,35$ & 3 & $10,20,30$ \\
\hline 7 & sition and diameter class distri- & 3 & $0,0.5,0.7$ & 3 & $0,20,30$ & 3 & $10,20,40$ \\
\hline 8 & $\begin{array}{l}\text { butions determines variation in } \\
\text { CWP }\end{array}$ & 15 & $\begin{array}{l}0,0.4,0.45,0.5,0.55,0.6,0.625,0.65,0.675 \\
0.7,0.725,0.75,0.775,0.8,0.85\end{array}$ & & & 3 & $10,20,40$ \\
\hline
\end{tabular}

Table 3. Results of whether the predictions of CWP based on the eight models: (a) correlate with the observed values (slope coefficient, F and $\mathrm{p}$ values from ANCOVA shown), and (b) predict the observed regional pattern in CWP (based on whether there is a significant regional term in an ANCOVA of observed versus predicted values; $\mathrm{F}$ and $\mathrm{p}$ values shown).

\begin{tabular}{|c|c|c|c|c|c|c|c|}
\hline \multirow[t]{2}{*}{ Model } & \multicolumn{4}{|c|}{$\begin{array}{l}\text { (a) Do predictions of CWP correlate } \\
\text { with the observed values? }\end{array}$} & \multicolumn{3}{|c|}{$\begin{array}{l}\text { (b) Do estimates of CWP predict the } \\
\text { observed, regional variation in CWP? }\end{array}$} \\
\hline & & Coeff. & $\mathrm{F}$ & $\mathrm{p}$ & & $\mathrm{F}$ & $\mathrm{p}$ \\
\hline 1 & No & 0.45 & 0.07 & $\mathrm{~ns}$ & No & 38.3 & $<0.001$ \\
\hline 2 & No & 0.47 & 0.001 & ns & No & 37.9 & $<0.001$ \\
\hline 3 & Yes & -0.08 & 6.8 & $<0.05$ & No & 31.3 & $<0.001$ \\
\hline 4 & Yes & -0.08 & 11.8 & $<0.01$ & No & 28.9 & $<0.001$ \\
\hline 5 & Yes & -0.17 & 10.0 & $<0.01$ & No & 31.1 & $<0.001$ \\
\hline 6 & Yes & 0.26 & 5.76 & $<0.05$ & No & 33.2 & $<0.001$ \\
\hline 7 & Yes & 0.35 & 7.6 & $<0.01$ & No & 32.5 & $<0.001$ \\
\hline 8 & Yes & 0.18 & 4.3 & $<0.05$ & No & 32.9 & $<0.001$ \\
\hline
\end{tabular}

and 3). This association between CWP and traits is stronger for wood density than for maximum height.

\subsection{Relationships between estimated and observed values of CWP}

Estimates of CWP using the Chambers et al. (2000) or Chave et al. (2005) equations were closely correlated (cf. Peacock et al., 2007). These close correlations mean that the choice of biomass equation does not alter the conclusions about the role of variation in functional composition for determining differences in CWP and we report further values using the equation based on the Manaus allometric relationship (Chambers et al., 2000), consistent with the method used to estimate wood production in Malhi et al. (2004).
For all of the models, the estimates of CWP are not closely related to the observed values of CWP (Table 3, Fig. 4). However, the performance of different models did vary. For example, estimates of CWP based solely on variation in diameter-class distributions are not significantly correlated with the observed values (models 1 and 2, Table 3, Fig. 4). In contrast, estimates of CWP based solely on variation in functional composition did have a significant correlation with the observed values (models 3-5, Table 3, Fig. 4). However, in these cases, the correlation was weakly negative (Table 3 ), suggesting that if variation in functional composition was the main driver of variation in CWP, the actual pattern would be the opposite to that which is observed.

The most successful models were those that included variation in both diameter-class, and functional-trait distributions. Within each region, estimates under this group of 

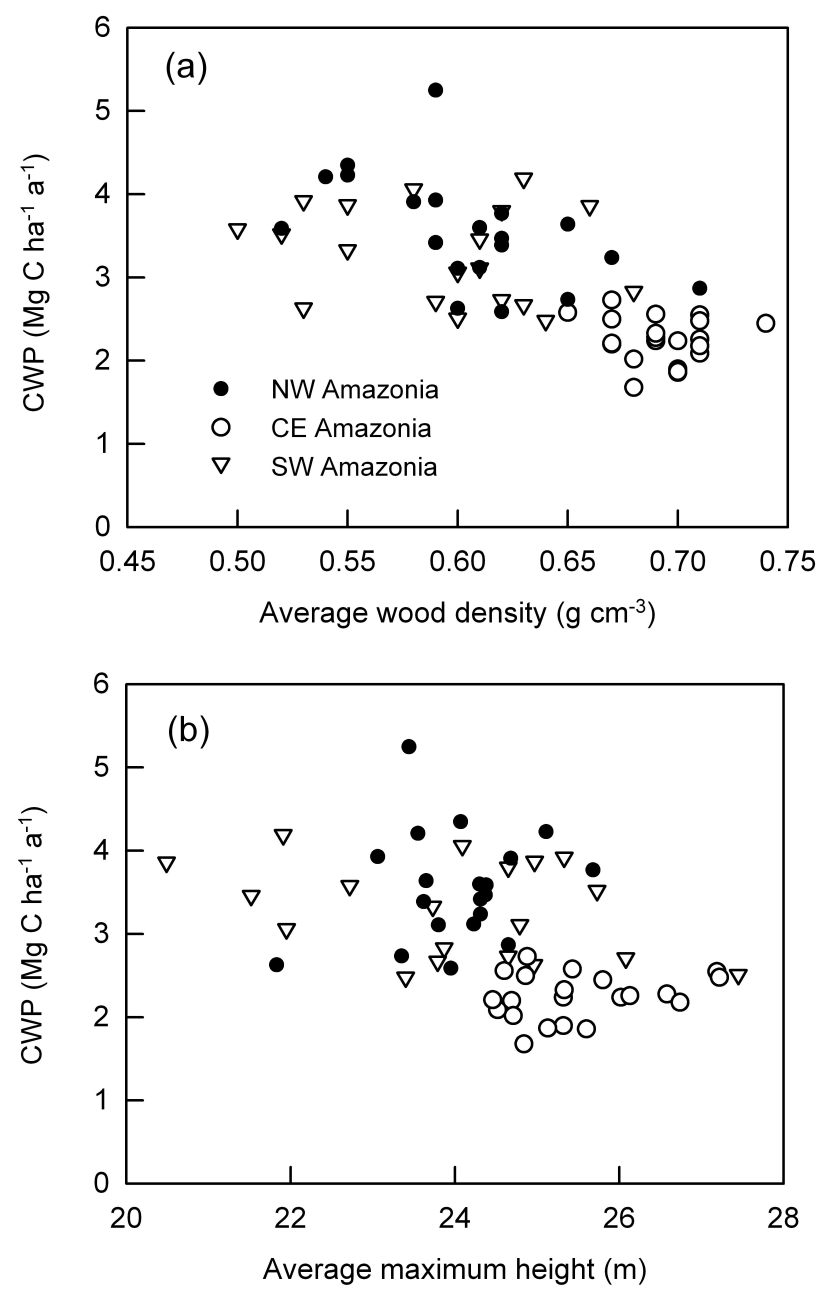

Fig. 3. Relationship between (a) average wood density and (b) average maximum height per plot calculated on a stems basis, and CWP for 60 Amazonian forest plots.

models were weakly positively correlated with the observed values (Table 3). However, even in these cases, the estimated values did not predict the observed regional difference in CWP (Table 3). Overall, these results suggest that in this network of forest plots, variation in functional composition does not cause the regional-scale variation in CWP.

The alternative explanation for the regional gradient in CWP is that environmental factors lead to higher growth rates across all types of tree in Western Amazonia. This explanation is supported by the consistent spatial patterns in biomass growth rates across all types of tree (Fig. 5). In seven out of the nine combinations of traits defined by model 7 , biomass growth rates are significantly lower in Central and Eastern, compared to Western Amazonia (Fig. 5).

\section{Model 1}

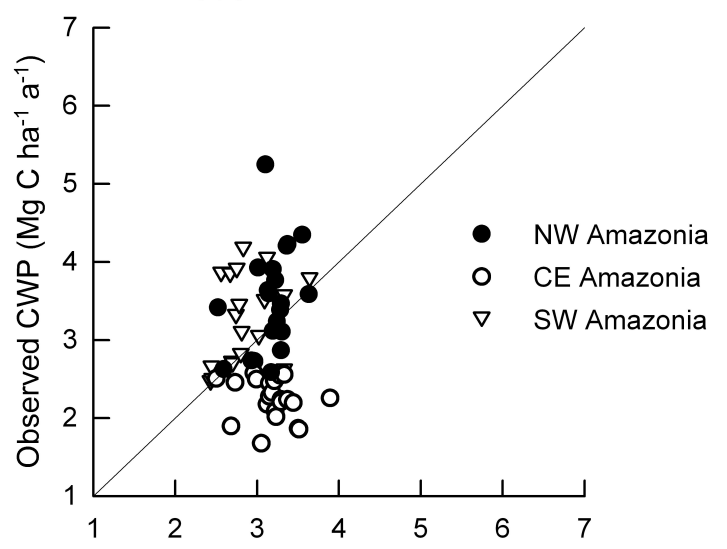

Model 4

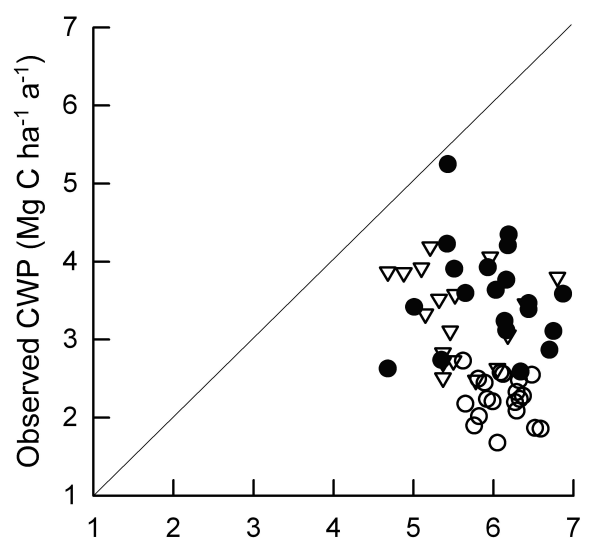

Model 7

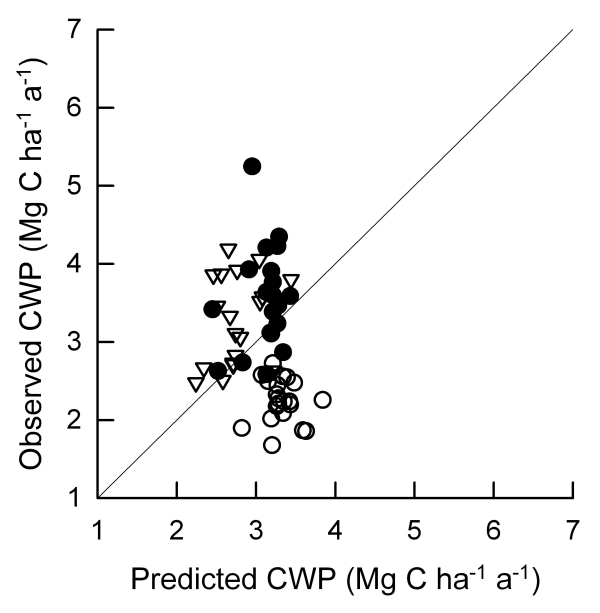

Fig. 4. Relationship between observed CWP and estimated values based on representative results from each group of models; results for model 1 (importance of diameter-class distributions), model 4 (importance of functional composition), and model 7 (importance of both diameter-class and functional composition) shown. For each graph, 1:1 line also shown. 


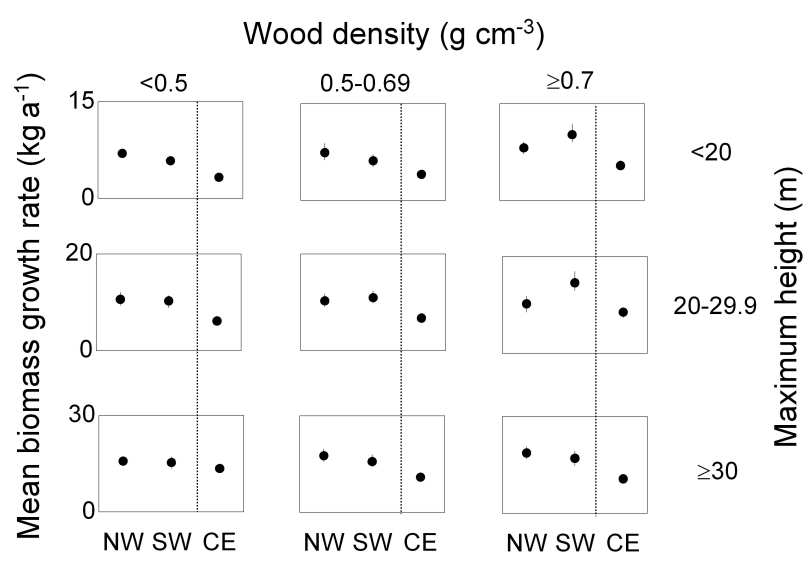

Fig. 5. Mean $( \pm 95 \%$ confidence limits $)$ biomass growth rates $\left(\mathrm{kg} \mathrm{a}^{-1}\right)$ for trees from nine functional classes based on the binsizes used for model 7 (Table 2) in Northwestern (NW), Southwestern (SW) and Central and Eastern (CE) Amazonia. Mean and 95\% confidence limits calculated from 1000 replicates of 100 stems resampled from each group from the original data. Error bars not visible are smaller than the data point; dotted lines separate results for Western and Eastern Amazonian regions.

\section{Discussion}

Although there is a correlation between the functional composition and CWP of Amazonian forests (Fig. 3), our results suggest that the variation in trait values does not cause the regional variation in CWP (Table 3, Fig. 4). In contrast, the direct effect of environmental factors on the biomass growth rates of all types of tree appears to be the main driver of these regional differences (Fig. 5). Overall, for a given forest, the characteristics of its location, rather than its composition, determine CWP.

The association between wood density and CWP described by the initial regression analysis matches previously published results (Malhi et al., 2004; Baker et al., 2004b). However, the relationship between maximum height and CWP has not been noted previously. The lower communitylevel maximum height in plots in Western compared to Central and Eastern Amazonia (Fig. 2) is consistent with studies that have suggested that the forests near Manaus contain few specialist understorey species (Gentry and Emmons, 1987) and have a smaller proportion of shrubs species than other Amazonian sites (Phillips et al., 2003). In addition, in a pan-tropical comparison of sapling communities, the highest abundance of small-statured species was found in a Western Amazon forest (LaFrankie et al., 2006). These patterns suggest that a suite of plant families contribute to a distinctive, diverse and abundant understorey flora in Western Amazonia. Such variation in community-level maximum height between tropical forests could be associated with variation in soil fertility, disturbance rates, drought or biogeographical factors (Pitman et al., 2006; Swaine and Becker, 1999;
Poorter et al., 2008a; LaFrankie et al., 2006). At a regional scale within Amazonia, variation in soil fertility may be particularly important, following the suggestion of Gentry and Emmons, (1987) that seasonal drought in combination with low soil fertility is a strong limitation to growth and reproduction in the shade in Central Amazonia. This idea is supported by correlations between soil fertility and average maximum height: for the plots where average values of soil sum of bases $(S B)$ are available (Quesada et al. this issue), average maximum height is significantly negatively correlated with $\log [S B]$, when calculated on a stems $\left(t=-3.65, r^{2}=0.23\right.$, $p<0.001)$, species $\left(t=-3.54, r^{2}=0.22, p<0.005\right)$ or basalarea basis $\left(t=-3.56 r^{2}=0.22, p<0.001\right)$. Experimental work on seedling growth is also consistent with this suggestion as root competition is a greater limitation to growth in the understorey on nutrient-poor compared to nutrient-rich soils in tropical forests (Lewis and Tanner, 2000; Barberis and Tanner, 2005). Higher soil fertility may also be associated with higher understorey light levels, through its relationship with tree mortality rates (Phillips et al., 2004), which may also promote the growth of understorey plants in these forests.

Despite mechanisms that might link variation in soil fertility with the changes in community-level trait distributions in different sites, it appears that the much larger direct effect of variation in environmental conditions on the growth rate of all types of tree is the most important factor determining the regional-scale pattern of CWP. None of the resampled estimates of CWP, based on various definitions of the underlying trait- and diameter-class distributions, capture the observed variation in CWP between regions (Table 3). Indeed, if differences in functional composition were the only factor determining variation in CWP between sites, then the observed values should be higher in the Central and Eastern Amazon plots (Table 3; Fig. 4, models 3-5).

The few studies of biomass increment in mature tropical trees support the idea that differences in biomass growth rates between species that differ in wood density are small and therefore have only a limited potential to affect stand-level patterns of CWP. Chambers et al. (2004) found no difference in rates of biomass increment across 72 tree species when the biomass estimates incorporated interspecific variation in wood density, and in dry forest in Mexico, Enquist et al. (1999) found that variation in diameter growth rates was smaller when they were adjusted for interspecific variation in wood density. In a study that controlled for variation in light availability, edaphic conditions and climate, Keeling et al. (2008) found that on fertile soils in Northwestern Amazon forests, trees of high wood density species have higher rates of biomass increment than species with low wood density, potentially related to the development of deeper crowns or lower root:shoot ratios. Scaled to the stand level, this pattern is consistent with the weak tendency for resampled stands with high wood density species to have the highest CWP (Table 3, models 3-5). However, overall, our results suggest that the effects of functional composition are weak, 
and environmental factors strong, on regional-scale patterns of CWP in Amazonia. Variation in edaphic conditions may be an important driver of these patterns (Malhi et al., 2004), consistent with studies that have shown increased growth following fertilisation in a range of tropical forests (e.g. Tanner et al., 1998).

In contrast to these conclusions, experimental studies of grassland ecosystems have demonstrated that functional composition, such as the presence of nitrogen fixing, nonnitrogen fixing, annual or perennial species, can influence net primary productivity (e.g. Wardle et al., 2000). One explanation for our opposite conclusions may concern the traits that we studied. There may be important variation amongst traits (e.g. specific leaf area, though note Poorter et al., 2008b) or functional groups (e.g. nitrogen/non-nitrogen fixers) of tropical trees that were not studied here, that may influence spatial patterns of productivity. We also did not consider the contribution to productivity made by a range of life forms (e.g. palms, lianas) that could introduce a stronger influence of biodiversity on total productivity. In particular, accurate measurements of the leaf productivity of the abundant palms in the plots of Southwestern Amazonia is required to determine the contribution of these trees to the total aboveground productivity in these sites. A second explanation is that the differences in functional composition in Amazonian forests may be too small to have a detectable impact on CWP. For example, in tropical agroforestry systems, in comparisons of very different lifeforms such as between maize and tree crops, productivity can vary greatly at the same site (Ewel and Bigelow 1996). However, productivity does not differ between more similar species combinations, such as enriched versus natural successional forest vegetation (Ewel and Bigelow 1996).

A third, related explanation is that the large influence of environmental factors in broad-scale field comparisons of productivity makes it difficult to detect small compositional effects. In general, relationships between biodiversity and ecosystem functioning may differ depending on the scale of study (e.g. for invasion resistance, Levine, 2000). Field studies of the relationship between productivity and plant traits are often carried out within single areas (e.g. Garnier et al., 2004), at spatial scales where effects of species characteristics will be more easily detected (Lavorel and Garnier, 2002). At larger scales, it may be more difficult to detect these relationships. For example, in terms of the effect of species richness on productivity in forests at large spatial scales, Vilà et al. (2003) found no effect when variation due to climate and bedrock was also considered in a study of pine forests in Spain, and Vilà et al. (2007) report a small, but significant, effect in Mediterranean forests. However, even in the second case, the significant effects of environmental variables were far larger than the effect of species richness.

A key limitation to understanding the effects of functional composition on CWP in tropical forests is the lack of detailed information about the diameter/biomass relationships for different species and functional groups. Here, we assume that differences, due to variation in stem form or the proportion of crown biomass, are small, both between forests and functional types (cf Keeling et al., 2008). For example, in terms of how diameter/biomass relationships may vary between species, it is noteworthy that the proportion of crown biomass does not vary with wood density class for a dataset of 90 trees from Brazil (Keeling et al., 2008). Also, in terms of structural differences between forests studied here, there is no significant difference between regions in asymptotic canopy height (mean $31.5 \pm 1.5 \mathrm{~m}$; T. R. Baker unpublished data) based on height data for 1060 trees from 24 of these plots. Although this data is from a limited number of plots compared to our full dataset, it suggests there is a degree of similarity in the canopy structure of these forests. In addition, Chave et al. (2005) found that neither site nor forest type was a significant variable in distinguishing distinct allometric relationships from a pan-tropical compilation of tree biomass data. These results suggest that our assumptions are not unreasonable, although the development of tree biomass datasets in Western Amazonia will allow us to test more fully whether current models for Amazonia developed in Brazil are applicable across the wider region.

A further limitation of our study is the use of trait values from the literature rather than from direct measurements on individual trees within the plots. Current literature compilations do not distinguish the components of trait variation due to genetic or environmental factors, and there is increasing evidence of important effects of environmental factors on trait values in tropical forests. For example, Patiño et al. (2008) find considerable plasticity in the branch wood density of widespread species in Amazonia, suggesting that environmental variation may have an important influence on wood density values of species in any particular location. In general, incorporating intraspecific variation in trait values is an important challenge in biodiversity/ecosystem function research (Hooper et al., 2005). Our resampling approach, where we defined functional-trait distributions using different bin sizes, allows for some site-specific variation in trait values. More broadly, formally considering the separate effects of the distinct genetic and environmental components of trait variation on tree growth, is likely to reinforce the role that environmental factors play in determining CWP, not only directly, but also through modifying plant traits.

In conclusion, it is noteworthy that the relationship between plant traits and ecosystem properties differs for wood productivity and biomass in Amazonian forests. This difference could have important implications for how changes in species composition affect ecosystem function. As wood density is an important trait in biomass estimation (Chave et al., 2005), spatial variation in this trait directly influences variation in biomass estimates (Baker et al., 2004b). As a result, compositional changes that alter community-averaged values of wood density may therefore markedly alter forest biomass (cf. Bunker et al., 2005). One mechanism that might 
lead to such a change in forest functional composition is the observed increase in the rate of tree turnover in Amazonian forests (Phillips et al., 2004) that may favour species with lower wood density. In more general terms, as wood density is closely associated to response traits related to disturbance and is also an important effect trait related to biomass, compositional change driven by this mechanism would lead to a large change in this ecosystem property (Suding et al., 2008). In contrast, as CWP is only weakly determined by trait variation in wood density, in contrast to forest biomass, CWP may be less sensitive to such trajectories of compositional change.

Acknowledgements. RAINFOR field campaigns contributing to this study were funded by the Royal Geographic Society, CARBONSINK-LBA and the Max Planck Institut für Biogeochemie. We gratefully acknowledge the support and funding of organisations who have contributed to the establishment and maintenance of individual sites: Natural Environment Research Council, EU Framework V and VI, US National Geographic Society, WWF-US/Garden Club of America, US National Science Foundation, the Nature Conservancy/Mellon Foundation (Ecosystem Function Program), Conselho Nacional de Desenvolvimento Cientifico e Tecnológico (CNPq), Museu Goeldi, Estacão Cientifica Ferreira Penna, Andrew W. Mellon Foundation, NASA-LBA Program, Conservation, Food and Health Foundation, MacArthur Foundation, Fundación Jatun Sacha, Estación Científica Yasuní de la Pontificia Universidad Católica del Ecuador, Estación de Biodiversidad Tiputini, Conservation International, ACEER, Albergue Inkaterra, Explorama Tours S.A., Explorers Inn, IIAP, INRENA, UNAP and UNSAAC. This study benefited from meetings organised by Y. Malhi and F. I. Woodward, and discussions with J. Chave, H. ter Steege, I. Lawson, J. Taylor, I. Hunter and E. Honorio. TRB acknowledges financial support from a NERC postdoctoral fellowship, NE/C517484/1 and a RCUK fellowship at the University of Leeds.

Edited by: F. Carswell

\section{References}

Baker, T. R., Swaine, M. D., and Burslem, D. F. R. P.: Variation in tropical forest growth rates: combined effects of functional group composition and resource availability, Perspectives in Plant Ecology, Evol. Syst., 6, 21-36, 2003.

Baker, T. R., Phillips, O. L., Malhi, Y., Almeida, S., Arroyo, L., Di Fiore, A., Erwin, T., Higuchi, N., Killeen, T. J., Laurance, S. G., Laurance, W. F., Lewis, S. L., Monteagudo, A., Neill, D. A., Vargas, P. N., Pitman, N. C. A., Silva, J. N. M., and Martinez, R. V.: Increasing biomass in Amazonian forest plots, Philos. Trans. R. Soc. Lond. Ser. B-Biol. Sci., 359, 353-365, 2004 a.

Baker, T. R., Phillips, O. L., Malhi, Y., Almeida, S., Arroyo, L., Di Fiore, A., Erwin, T., Killeen, T. J., Laurance, S. G., Laurance, W. F., Lewis, S. L., Lloyd, J., Monteagudo, A., Neill, D. A., Patino, S., Pitman, N. C. A., Silva, J. N. M., and Martinez, R. V.: Variation in wood density determines spatial patterns in Amazonian forest biomass, Global Change Biol., 10, 545-562, 2004b.

Balvanera, P., Kremen, C., and Martineez-Ramos, M.: Applying community structure analysis to ecosystem function: examples from pollination and carbon storage, Ecol. Appl., 15, 360-375, 2005.

Barberis, I. M. and Tanner, E. V. J.: Gaps and root trenching increase tree seedling growth in Panamanian semi-evergreen forest, Ecology, 86, 667-674, 2005.

Bunker, D. E., DeClerck, F., Bradford, J. C., Colwell, R. K., Perfecto, I., Phillips, O. L., Sankaran, M., and Naeem, S.: Species loss and aboveground carbon storage in a tropical forest, Science, 310, 1029-1031, 2005.

Chambers, J. Q., dos Santos, J., Ribeiro, R. J., and Higuchi, N.: Tree damage, allometric relationships, and above-ground net primary production in central Amazon forest, For. Ecol. Manage., 5348, 1-12, 2000.

Chambers, J. Q., Higuchi, N., Teixeira, L. M., dos Santos, J., Laurance, S. G., and Trumbore, S. E.: Response of tree biomass and wood litter to disturbance in a Central Amazon forest, Oecologia, 141, 596-611, 2004.

Chave, J.: Study of structural, successional and spatial patterns in tropical rain forests using TROLL, a spatially explicit forest model, Ecol. Model., 124, 233-254, 1999.

Chave, J., Andalo, C., Brown, S., Cairns, M. A., Chambers, J. Q., Eamus, D., Folster, H., Fromard, F., Higuchi, N., Kira, T., Lescure, J. P., Nelson, B. W., Ogawa, H., Puig, H., Riera, B., and Yamakura, T.: Tree allometry and improved estimation of carbon stocks and balance in tropical forests, Oecologia, 145, 8799, 2005.

Chave, J., Muller-Landau, H. C., Baker, T. R., Easdale, T. A., ter Steege, H., and Webb, C. O.: Phylogenetic conservatism and regional variation in wood density among neotropical tree species, Ecol. Appl., 16, 2356-2367, 2006.

Dixon, R. K., Brown, S., Houghton, R. A., Solomon, A. M., Trexler, M. C., and Wisniewski, J.: Carbon pools and flux of global forest ecosystems, Science, 263, 185-190, 1994.

Enquist, B., West, G. B., Charnov, E. L., and Brown, J. H.: Allometric scaling of production and life-history variation in vascular plants, Nature, 401, 907-911, 1999.

Falster, D. S. and Westoby, M.: Alternative height strategies among 45 dicot rain forest species from tropical Queensland, Australia, J. Ecol., 93, 521-535, 2005.

Galwey, N. W.: Introduction to Mixed Modelling: Beyond Regression and Analysis of Variance. Wiley, Chichester, England, Hoboken, NJ, USA, 376 pp, 2006.

Garnier, E., Cortez, J., Billès, G., Navas, M.-L., Roumet, C., Debussche, M., Laurent, G., Blanchard, A., Aubry, D., Bellmann, A., Neill, C., and Toussaint, J.-P.: Plant functional markers capture ecosystem properties during secondary succession, Ecology, 85, 2630-2637, 2004.

Gentry, A. H. and Emmons, L. H.: Geographical variation in fertility, phenology, and composition of the understory of Neotropical forests, Biotropica, 19, 216-227, 1987.

Hooper, D. U., Chapin, F. S., Ewel, J. J., Hector, A., Inchausti, P., Lavorel, S., Lawton, J. H., Lodge, D. M., Loreau, M., Naeem, S., Schmid, B., Setala, H., Symstad, A. J., Vandermeer, J., and Wardle, D. A.: Effects of biodiversity on ecosystem functioning: A consensus of current knowledge, Ecol. Monogr., 75, 3-35, 2005.

Keeling, H. C., Baker, T. R., Vasquez Martinez, R., Monteagudo, A., and Phillips, O. L.: Contrasting patterns of diameter and biomass increment across tree functional groups in Amazonian forests, Oecologia, 158, 521-534, 2008. 
Killeen, T. J., Garcia E., E., and Beck, S. G.: Guia de arboles de Bolivia, Missouri Botanic Garden, St. Louis, USA, 958 pp., 1993.

LaFrankie, J. V., Ashton, P. S., Chuyong, G., Co, L., Condit, R., Davies, S. J., Foster, R. B., Hubbell, S. P., Kenfack, D., Lagunzad, D., Losos, E. C., Nor, N. S. M., Tan, S., Thomas, D. W., Valencia, R., and Villa, G.: Contrasting structure and composition of the understorey in species-rich tropical rainforests, Ecology, 87, 2298-2305, 2006.

Laurance, W. F., Oliveira, A. A., Laurance, S. G., Condit, R., Nascimento, H. E. M., Sanchez-Thorin, A. C., Lovejoy, T. E., Andrade, A., D’Angelo, S., Ribeiro, J. E., and Dick, C. W.: Pervasive alteration of tree communities in undisturbed Amazonian forests, Nature, 428, 171-175, 2004.

Lavorel, S. and Garnier, E.: Predicting changes in community composition and ecosystem functioning from plant traits: revisiting the Holy Grail, Func. Ecol., 16, 545-556, 2002.

Levine, J. M.: Species diversity and biological invasions: relating local process to community pattern, Science, 288, 852-854, 2000.

Lewis, S. L. and Tanner, E. V. J.: Effects of above- and belowground competition on growth and survival of rain forest tree seedlings, Ecology, 81, 2525-2538, 2000.

Lieberman, D. and Lieberman, M.: Forest tree growth and dynamics at La Selva, Costa Rica (1969-1982), J. Trop. Ecol., 3, 347358, 1987.

Malhi, Y., Phillips, O. L., Baker, T., Almeida, S., Fredericksen, T., Grace, J., Higuchi, N., Killeen, T., Laurance, W. L., Leaño, C., Lloyd, J., Meir, P., Monteagudo, A., Neill, D., Núñez Vargas, P., Panfil, S., Pitman, N., Rudas Ll, A., Salamão, R., Saleska, S., Silva, N., Silveira, M., Sombroek, W. G., Valencia, R., Vásquez Martínez, R., Vieira, I., and Vinceti, B.: An international network to understand the biomass and dynamics of Amazonian forests (RAINFOR), J. Veg. Sci., 13, 439-450, 2002.

Malhi, Y., Baker, T. R., Phillips, O. L., Almeida, S., Alvarez, E., Arroyo, L., Chave, J., Czimczik, C. I., Di Fiore, A., Higuchi, N., Killeen, T. J., Laurance, S. G., Laurance, W. F., Lewis, S. L., Montoya, L. M. M., Monteagudo, A., Neill, D. A., Vargas, P. N., Patino, S., Pitman, N. C. A., Quesada, C. A., Salomao, R., Silva, J. N. M., Lezama, A. T., Martinez, R. V., Terborgh, J., Vinceti, B., and Lloyd, J.: The above-ground coarse wood productivity of 104 Neotropical forest plots, Global Change Biol., 10, 563-591, 2004.

Patiño, S., Lloyd, J., Paiva, R., Quesada, C. A., Baker, T. R., Santos, A. J. B., Mercado, L. M., Malhi, Y., Phillips, O.L., Aguilar, A., Alvarez, E., Arroyo, L., Bonal, D., Costa, A. C. L., Czimczik, C. I., Gallo, J., Herrera, R., Higuchi, N., Horna, V., Hoyos, E. J., Jiménez, E. M., Killeen, T., Leal, E., Luizão, F., Meir, P., Monteagudo, A., Neill, D. A., Núñez-Vargas, P., Palomino, W., Peacock, J., Peña-Cruz, A., Peñuela, M. C., Pitman, N. C. A., Priante Filho, N., Prieto, A., Panfil, S. N., Rudas, A., Salomão, R., Silva, N. M., Silveira, M., Soares de Almeida, S., Torres-Lezama, A., Turriago, J. D., Vásquez, R., Schwarz, M., Sota, A., Schmerler, J., Vieira, I., Villanueva, B. and Vitzthum, P.: Branch xylem density variations across the Amazon Basin, Biogeosciences Discuss., 5, 2003-2047, 2008, http://www.biogeosciences-discuss.net/5/2003/2008/.

Peacock, J., Baker, T. R., Lewis, S. L., Lopez-Gonzalez, G., and Phillips, O. L.: The RAINFOR database: monitoring forest biomass and dynamics, J. Veg. Sci., 18, 535-542, 2007.
Phillips, O. L., Vásquez, R., Arroyo, L., Baker, T. R., Killeen, T., Lewis, S., Malhi, Y., Monteagudo, A., Neill, D., Núñez Vargas, P., Alexiades, M., Cerón, C., Di Fiore, A., Erwin, T., Jardim, A., Palacios, W., Saldias, M., and Vinceti, B.: Increasing dominance of large lianas in Amazonian forests, 2002.

Phillips, O. L., Martinez, R. V., Vargas, P. N., Monteagudo, A. L., Zans, M. E. C., Sanchez, W. G., Cruz, A. P., Timana, M., YliHalla, M., and Rose, S.: Efficient plot-based floristic assessment of tropical forests, J. Trop. Ecol., 19, 629-645, 2003.

Phillips, O. L., Baker, T. R., Arroyo, L., Higuchi, N., Killeen, T. J., Laurance, W. F., Lewis, S. L., Lloyd, J., Malhi, Y., Monteagudo, A., Neill, D. A., Vargas, P. N., Silva, J. N. M., Terborgh, J., Martinez, R. V., Alexiades, M., Almeida, S., Brown, S., Chave, J., Comiskey, J. A., Czimczik, C. I., Di Fiore, A., Erwin, T., Kuebler, C., Laurance, S. G., Nascimento, H. E. M., Olivier, J., Palacios, W., Patino, S., Pitman, N. C. A., Quesada, C. A., Salidas, M., Lezama, A. T., and Vinceti, B.: Pattern and process in Amazon tree turnover, 1976-2001, Philos. Trans. R. Soc. Lond. Ser. B-Biol. Sci., 359, 381-407, 2004.

Pitman, N. C. A., Terborgh, J. W., Silman, M. R., Núñez, P. V., Neill, D. A., Cerón, C., Palacios, W. A., and Aulestia, M.: Dominance and distribution of tree species in upper Amazonian terra firme forests, Ecology, 82, 2101-2117, 2001.

Pitman, N. C. A., Cerón, C., Reyes, C. I., Thurber, M., and Arellano, J.: Catastrophic natural origin of a species-poor tree community in the world's richest forest, J. Trop. Ecol., 21, 559-568, 2006.

Poorter, L., Hawthorne, W., Bongers, F., and Sheil, D.: Maximum size distributions in tropical forest communities: relationships with rainfall and disturbance, J. Ecol., 96, 495-504, 2008a.

Poorter, L., Wright, S. J., Paz, H., Ackerly, D. D., Condit, R., IbarraManriquez, G., Harms, K. E., Licona, J. C., Martinez-Ramos, M., Mazer, S. J., Muller-Landau, H., Pena-Claros, M., Webb, C. O., and Wright, I. J.: Are functional traits good predictors of demographic rates? Evidence from five neotropical forests, Ecology, 89, 1908-1920, 2008b.

Quesada, C. A., Lloyd, J., Schwarz, M., Baker, T. R., Phillips, O. L., Patiño, S., Czimczik, C. I., Hodnett, M., Herrera, R., Arneth, A., Lloyd, G., Malhi, Y., Dezzeo, N., Luizão, F. J., Santos, A. J. B., Schmerler, J., Arroyo, L., Silveira, M., Priante Filho, N., Jiménez, E. M., Paiva, R., Vieira, I., Neill, D. A., Silva, N. M., Peñuela, M. C., Monteagudo, A., Vásquez, R., Prieto, A., Rudas, A., Almeida, S., Higuchi, N., Lezama, A. T., López-González, G., Peacock, J., Fyllas, N. M., Alvarez Dávila, E., Erwin, T., di Fiore, A., Chao, K.-J., Honorio, E. N., Killeen, T. J., Peña Cruz, A., Pitman, N. C. A., Núñez, P., Salomão, R., Terborgh, J. and Ramírez, H.: Regional and large-scale patterns in Amazon forest structure and function are mediated by variations in soil physical and chemical properties, Biogeosciences Discuss., accepted, 2009.

Ribeiro, J. E. L. d. S., Hopkins, M. J. G., Vicentini, A., Sothers, C. A., Costa, M. A. d. S., Brito, J. M. d., Souza, M. A. D. d., Martins, L. H. P., Lohmann, L. G., Assunção, P. A. C. L., Pereira, E. d. C., Silva, C. F. d., Mesquita, M. R., and Procópio, L. C.: Flora da Reserva Ducke, INPA-DFID, 799 pp., 1999.

Santiago, L. S., Goldstein, G., Meinzer, F. C., Fisher, J. B., Machado, K., Woodruff, D., and Jones, T.: Leaf photosynthetic traits scale with hydraulic conductivity and wood density in Panamanian forest canopy trees, Oecologia, 140, 543-550, 
2004.

Sombroek, W.: Amazon landforms and soils in relation to biological diversity, Acta Amazonica, 30, 81-100, 2000.

Sombroek, W. G.: Spatial and temporal patterns of Amazon rainfall, Ambio, 30, 388-396, 2001.

Suding, K. N., Lavorel, S., Chapin, F. S., Cornelissen, J. H. C., Diaz, S., Garnier, E., Goldberg, D., Hooper, D. U., Jackson, S. T., and Navas, M.-L.: Scaling environmental change through the community-level: a trait-based response-and-effect framework for plants, Global Change Biol., 14, 1125-1140, 2008.

Swaine, M. D. and Becker, P.: Woody life-form composition and association on rainfall and soil fertility gradients in Ghana, Plant Ecol., 145, 167-173, 1999.

ter Steege, H., Pitman, N., Phillips, O. L., Chave, J., Sabatier, D., Duque, A., Molino, J.-F., Prévost, M.-F., Spichiger, R., Castellanos, H., von Hildebrand, P., and Martinez, R. V.: Continental scale patterns of canopy tree composition and function across Amazonia, Nature, 443, 444-447, 2006.
Thomas, S. C. and Bazzaz, F. A.: Asymptotic height as a predictor of photosynthetic characteristics in Malaysian forest trees, Ecology, 80, 1607-1622, 1999.

Turner, I. M.: The Ecology of Trees in the Tropical Rain Forest, Cambridge University Press, Cambridge, 2001.

Vásquez Martínez, R.: Flórula de las Reservas Biológicas de Iquitos, Perú, Monographs in Systematic Botany from the Missouri Botanical Garden, edited by: Lleras, A. R. and Taylor, C. M., Missouri Botanical Garden, St. Louis, USA, 1046 pp., 1997.

Vilà, M., Vayreda, J., Gracia, C., and Ibanez, J. J.: Does tree diversity increase wood production in pine forests?, Oecologia, 135, 299-303, 2003.

Vilà, M., Vayreda, J., Comas, L., Ibáñez, J., Mata, T., and Obón, B.: Species richness and wood production: a positive association in Mediteranean forests, Ecol. Lett., 10, 241-250, 2007.

Wardle, D. A., Bonner, K. I., and Barker, G. M.: Stability of ecosystem properties in response to above-ground functional group richness and composition, Oikos, 89, 11-23, 2000. 